\title{
The Effect of E-Commerce Application Service Quality of Customer Loyalty Using Customer Relationship Management Approach
}

\author{
${ }^{1}$ Ali Ibrahim*, ${ }^{2}$ St Dhiah Raniah Napian ${ }^{3}$ Arni Firanisa, ${ }^{4}$ Sartika, ${ }^{5}$ Ratih
} Dewi Sari, ${ }^{6}$ Meitiana Audya

\author{
Ialiibrahim@unsri.ac.id, Information System, Computer Science Faculty of Sriwijaya University \\ Indonesia \\ ${ }^{3}$ arnifiranisa@gmail.com, Information System Study Program, Computer Science Faculty of Sriwijaya \\ University Indonesia \\ ${ }^{4}$ sartikatika1398@gmail.com, Information System Study Program, Computer Science Faculty of \\ Sriwijaya University Indonesia \\ ${ }^{5}$ ratih.dewisari88@gmail.com, Information System Study Program, Computer Science Faculty of \\ Sriwijaya University Indonesia \\ ${ }^{6}$ meitianaaudya9@gmail.com, Information System Study Program, Computer Science Faculty of \\ Sriwijaya University Indonesia \\ *Corresponding Author: aliibrahim@ilkom.unsri.ac.id
}

\begin{abstract}
.
The development of technology in the present is so rapid. More and more startups are emerging, resulting in increasingly fierce business competition. With the tight competition, companies must try to always achieve a competitive advantage. One of the efforts that can be made by the company is to increase the focus on customer satisfaction and loyalty using the CRM approach. One of the startups that developed in Indonesia is e-commerce. Based on data collected by price, from 2017 to the end of 2018 Shopee is one of the most visited e-commerce sites. Therefore, the authors are interested in knowing the influence of e-commerce application service quality on Sriwijaya University Student Loyalty. The data collection was done by distributing questionnaires to several students in each faculty of Sriwijaya University with a total of 50 respondents. Based on the questionnaire filled out by respondents, the results were obtained that that service quality has a positive influence on customer loyalty with a total influence of $17.2 \%$, this means that with increasing service quality, it affects the customer loyalty to e-commerce.
\end{abstract}

Keywords: Customer Relationship Management, customer loyalty, service loyalty

\section{INTRODUCTION}

Competition in the business world in the current era of globalization is getting tougher. One of the conditions for companies to compete in achieving sustainable competitive advantage in business is to focus on customers. In creating a business that focuses on customers, companies must have information related to their customers so they can find out the needs and desires of customers in order to achieve customer satisfaction. Satisfaction with customers can be realized using a marketing strategy that aims to create relationships between companies and customers, this strategy is known as Customer Relationship Management (CRM).Customer Relationship Management (CRM) is a method of business practice that is growing and very important in Indonesia today.
This CRM is used to manage interactions between companies and customers that occur in the present and have an impact on the future [1]. The task of the CRM approach is to analyze data about the customer's history with the company. This CRM focuses on how to retain customers because it helps sales growth. The implementation of the CRM process has the potential to significantly improve company performance at the stage of customer relationship maintenance [2]. Previous empirical research provides evidence that investment in CRM technology enhances CRM capabilities that have a positive influence on business performance [3].

Digital technology changes markets, business environments, and business models [4], as well as the marketing communication paradigm [5]. In this context, new media technologies that offer new 
ways for companies to achieve, interact with adjusting communication with customers are very relevant for the CRM process [6]. One of the digital media technologies used in business activities is E-Commerce. The existence of ECommerce increases the company's business competition by providing responses to customers. One form of E-Commerce in Indonesia is the Shopee online shop. Shopee has considerable potential used by marketers to market and sells merchandise.

Shopee Indonesia is one of the shopping centers managed by Garena (changed its name to SEA Group). The business of $\mathrm{C} 2 \mathrm{C}$ (customer to customer) mobile marketplace carried by Shopee allows its presence to be easily accepted by various layers of society, including in Indonesia [7]. Indonesian Shopee was officially introduced in Indonesia in December 2015 under the auspices of PT Shopee International Indonesia. Since its launch, Shopee Indonesia has experienced very rapid development, even as of October 2017 the application has been downloaded by more than 25 million users. In Indonesia, besides Shopee, there is a fairly high E-Commerce competition, namely Lazada, Tokopedia, Bukalapak, and Blibli.com. Clear and accurate information on E-Commerce can attract customers to shop because customers need information about the product to be purchased. Information on products or services provided must be in accordance with reality in order to satisfy customers. The more quality information provided can help customers make decisions, shop online. Consistent and easy to understand information can also affect customer loyalty.

Then before deciding to buy there are several factors that are taken into consideration including the quality of service, namely as the customer's perception of the quality of services provided by ecommerce. The more quality services provided, the higher the interest of customers to buy these products that create customer loyalty. In terms of Shopee service quality Offering a one-stop mobile experience, Shopee provides a live chat feature that makes it easy for sellers and buyers to interact easily and quickly. Customers who shop through the Shopee site are not charged shipping costs throughout Indonesia and guarantee returns if the customer feels dissatisfied with the product received. Shopee provides several payment mode options and this site has simple and intuitive navigation that speeds up and simplifies online shopping. The various service facilities provided by Shopee provide new colors in terms of shopping. ThereforeShopee online shopping is in great demand by various groups, as well as among students. Shopee was chosen by the student and because it has a free shipping service, has a complete product category and guarantees that the goods received are in good condition.
Based on the explanation above, quality is one factor for customer loyalty. This makes the writer interested in conducting a study entitled "The Effect of Service Quality on Shopee Applications on Unsri Student Loyalty Using the CRM Approach".

\section{LITERATURE REVIEW}

\section{Service Quality}

The development of the business world requires every company to have the advantage to face business competition. Service quality is one way that can be used to win a business competition by applying service quality and the right quality of products so as to increase customer satisfaction and create customer loyalty [8]. This is needed especially in the service sector. Companies engaged in services must be able to provide quality services so as not to lose customers in the long run. According to a paper written by Kusuma Wijayanto, there are factors that influence service quality developed by Parasuraman, Zeithalm and Berry, namely tangibles, reliability, responsiveness, assurance, and empathy (empathy) [9].

Service quality is carried out by providing service excellence carried out by service providers in meeting customer needs and desires as well as the accuracy of delivery to offset customer expectations [10]. Based on research conducted by Ade and Peter, the results of the study reflect the statements of Sweeney and Soutar (2001) that consumers value products not only from a functional or performance basis, money value, and usability but also in terms of the value of pleasure derived from the product (emotional value) and social values [11]. By positioning focus on service quality in reliability and assurance, companies can obtain higher attitude loyalty and long-term profitability [12]. So, service quality is one of the important things that must be considered in increasing customer satisfaction with company services for a long time.

\section{Customer Loyalty}

Loyalty is someone's loyalty to an object. Consumers who return several times to buy services from the same company are loyal customers, but customer defection is not the opposite of customer loyalty and vice versa for several reasons such as availability or lack of choice [13]. According to Ellen Garbarino (1999), another potential factor that influences loyalty is a relationship commitment that is defined as a lasting desire to maintain valued relationships and an important element for successful long-term relationships. This is quoted in a paper written by 
Fei Cheng, Shan Wu and Chieh Chen [14]. In papers written by Christian, Rotinsulu, and Jacky, they cite the opinion of Kotler (2008) which defines that loyal consumers are not measured by how much they buy, but from how often they make repeat purchases, including recommending other people to buy [15]. So, a loyal consumer is someone who buys goods or services that make repeat purchases regularly, buy other products offered by the same producer, and recommend these service products to others.

\section{Social Customer Relationship Management}

Customer Relationship Management (CRM) is a customer-oriented business strategy, with the aim of finally maximizing company profits and customer satisfaction. CRM is defined as the integration of coordinated sales, marketing and service strategies[1]. CRM stores customer information and records all contacts that occur between customers and companies, and creates customer profiles for company staff who need information about these customers [16]. According to Laudon and Traver in the book E-Commerce (2016), Customer Relationship Management (CRM) is the process of storing customer information and recording all contacts that occur between customers and companies, as well as creating customer profiles for company staff who need information about these customers [17] Whereas according to research conducted by Dyanna et al, CRM is a marketing strategy to create and maintain good relationships with customers and reduce the likelihood of customers moving to other competitors [18]. Based on research conducted by Kubina and Lendel, we can now observe the use of more intensive information technology to collect and store information about clients. This trend is also reflected in the use of innovative approaches to relationship marketing, which give rise to a new type of customer relationship management (CRM)[2]. This is mainly electronic (e-CRM) and social (SCRM) CRM [19]. The increasing use of social media questions the ancient notion of customer relationship management (CRM). Social CRM Strategy is a new version of CRM that is empowered by social media technology that offers new ways to effectively manage customer relations [20].

\section{Online Shopping}

Online shopping or often referred to as online shopping is the activity of buying goods and services through the internet, a buyer can see in advance the goods and services that are going to be spent through the web or application used by the seller [21], this online shopping activity is a form of communication new ones that do not require face-to-face communication directly, [22] but can be done separately from and to the rest of the world through the media of notebooks, computers or mobile phones that are connected to internet access services. [23] [24] consumers who shop on the internet must wait for the product to be purchased before using it [25].

\section{RESEARCH METHODS}

\section{Type of Research}

In this study using a type of descriptive research using quantitative methods. According to Sugiyono (2008), descriptive research is research conducted to determine the value of independent variables by connecting these independent variables with other variables. In descriptive research has the purpose of solving a problem by describing the relationship of the independent variable (which affects) which consists of one or more variables with the dependent variable (which is affected). To find out the relationship between independent variables and other variables in a study, one of them used quantitative methods in the processing of research data. Quantitative methods, namely research methods used to determine the relationship between variables in a particular population or sample, in the process of collecting data using research instruments, statistical data analysis, which aims to test the hypothesis that has been set.

\section{Research Variable}

In this study, there are two variables, namely: Shopee application service quality as an independent variable or independent variable (variable $\mathrm{X}$ ) and UNSRI student loyalty as the dependent or bound variable (variable Y).

\section{Measurement Scale}

Measurements in this study based on the questionnaire used were using a Likert Scale in the range 1-4. The classification of the values on the questionnaire in the Likert scale includes: Strongly Agree $=4$, Agree $=3$, Disagree $=2$, Disagree $=1$.

\section{Population and Samples}

The population in this study were all Sriwijaya University students. For the sake of this research, from the population, a sample of 50 Sriwijaya University students from all faculties was taken. 


\section{Data Collection}

The data in the study are divided into two data, namely primary data and secondary data. Primary data is sourced from questionnaire results that have been filled in by respondents. While secondary data comes from the study of literature originating from journals and other information obtained from the internet.

Data collection techniques in this study, namely:

1. Literature study, namely by studying literature in the form of journals and books related to this research.

2. Using questionnaires (questionnaires) that are distributed through Google Form.

\section{Data Analysis Techniques}

The data analysis technique used in this study is a simple linear regression analysis. Regression Analysis use to find out and analyze the influence of Shopee application service quality on the loyalty of elementary students in shopping using the Shopee application, The regression equation used is as follows:

$$
Y=a+b x
$$

Note :

Y: the loyalty of Sriwijaya university students a: constant b: regression coefficient $\mathrm{X}$ : service quality

\section{RESULTS AND DISCUSSION}

\section{Manage data in SPSS}

After the process of collecting data through questionnaires made with Google form, the next step will be inputted data in SPSS based on the data type and will be processed through the SPSS application. Entered / Removed Variables to Describe the variables included and the methods used in linear regression analysis

Table 1. Variables Entered/Removed

\begin{tabular}{|l|l|l|l|}
\hline Model & $\begin{array}{l}\text { Variables } \\
\text { Entered }\end{array}$ & $\begin{array}{l}\text { Variables } \\
\text { Removed }\end{array}$ & Method \\
\hline 1 & $\begin{array}{l}\text { Service_ } \\
\text { Qualitya }\end{array}$ & $\cdot$ & Enter \\
\hline
\end{tabular}

1. All requested variables entered.

2. Dependent Variable:Customer_Loyalty

\section{Sample Linear Regression Equations}

Table 2. Coefficients for Constant values

Coefficients $^{\mathrm{a}}$

\begin{tabular}{|c|c|c|c|c|c|}
\hline \multirow[t]{2}{*}{ Model } & \multicolumn{2}{|c|}{$\begin{array}{c}\text { Unstandarlized } \\
\text { Coefficients }\end{array}$} & $\begin{array}{l}\text { Standarlized } \\
\text { Coefficients }\end{array}$ & \multirow[t]{2}{*}{$\mathrm{t}$} & \multirow[t]{2}{*}{ Sig. } \\
\hline & B & Std.Error & Beta & & \\
\hline $\begin{array}{c}1 \text { (Constant) } \\
\text { Service_- } \\
\text { Quality }\end{array}$ & 202 & $\begin{array}{r}2.008 \\
065\end{array}$ & 414 & $\begin{array}{r}4.276 \\
3.153\end{array}$ & $\begin{array}{l}.000 \\
003\end{array}$ \\
\hline
\end{tabular}

a. Dependent Variable: Customer_Loyalty

From Table 2 above it can be seen that: $\mathrm{a}=$ constant number of unstandardized coefficients. In this case, the value is 8,584 . This number is a constant number which means that if there is no Service_Quality (X) then the consistent value of the Loyalty_student $(\mathrm{Y})$ is 8.584 .

$\mathrm{b}=$ number of regression coefficients. The value is 0.204 . This number implies that for every $1 \%$ increase in service_quality $(\mathrm{X})$, then customer loyalty (Y) will increase by 0.204 .

Because the regression coefficient is positive $(+)$, then it can be said that Service_Quality (X) has a positive effect on student_loyalty (Y) so the regression equation is $\mathrm{Y}=8 . \overline{5} 84+0.204 \mathrm{X}$ 
Meanwhile, to ascertain whether the regression coefficient is significant or not (In the sense that the variable $\mathrm{X}$ influences the variable $\mathrm{Y}$ ). We can test this hypothesis by comparing significant values (sig). with a probability of 0.05 or by other means, namely comparing the calculated value $\mathrm{t}$ with t table.

\section{Hypothesis Test Comparing the Sig Value with 0.05}

Table 3. The coefficient for Sig Value

Coefficients $^{\mathrm{a}}$

\begin{tabular}{|c|c|c|c|c|c|}
\hline \multirow{2}{*}{ Model } & \multicolumn{2}{|c|}{$\begin{array}{c}\text { Unstandarlized } \\
\text { Coefficients }\end{array}$} & \multicolumn{2}{c|}{$\begin{array}{c}\text { Standarlized } \\
\text { Coefficients }\end{array}$} & Sig. \\
\cline { 2 - 4 } & $\mathrm{B}$ & Std.Error & \multicolumn{2}{|c|}{ Beta } & \\
\hline $\begin{array}{c}\text { Service_ } \\
\text { Quality }\end{array}$ & 8.584 & 2.008 & & 4.276 & .000 \\
\hline
\end{tabular}

a. Dependent Variable:Customer_Loyalty

Decision making in regression analysis by looking at the significance value (Sig.) Of SPSS output is:

1. If the significance value (Sig.) Is smaller $<$ than the probability of 0.05 implies that there is a Service_Quality (X) Effect on Loyalty_students (Y).

2. Conversely, if the significance value (Sig.) Is greater $>$ than the probability of 0.05 implies that there is no servicequality influence $(\mathrm{X})$ on the Loyalty_ student (Y).

Based on Table 3 above the output, it is known that the significance value (Sig.) Of 0.003 is smaller than <probability of 0.05 , so it can be concluded that $\mathrm{HO}$ is rejected and $\mathrm{Ha}$ is accepted,

3.

Table 4. Coefficients for Value of T Calculate which means that "There is a Service-Quality Effect (X) on Loyalty_student (Y)".

\section{Hypothesis Test Comparing the Value of T Calculate with T Table}

The basis for decision making in this t-test is:

1. If the value of $t$ counts is greater $>$ than $t$ table then there is a Service-Quality Effect (X) on Loyalty_student (Y) "

2. Conversely, if the value of $t$ counts is smaller <than t table then there is no Service-Quality Effect $(\mathrm{X})$ on customer Loyalty

(Y)

Coefficients $^{\mathrm{a}}$

\begin{tabular}{|c|c|c|c|c|c|}
\hline \multirow{2}{*}{ Model } & \multicolumn{2}{|c|}{$\begin{array}{c}\text { Unstandarlized } \\
\text { Coefficients }\end{array}$} & $\begin{array}{c}\text { Standarlized } \\
\text { Coefficients }\end{array}$ & \multirow{2}{*}{$\mathrm{t}$} & \multirow{2}{*}{ Sig. } \\
\cline { 2 - 4 } & $\mathrm{B}$ & Std.Error & Beta & & \\
\hline $\begin{array}{c}1 \text { (Constant) } \\
\begin{array}{c}\text { Service_ } \\
\text { Quality }\end{array}\end{array}$ & 8.584 & 2.008 & & 4.276 & .000 \\
\hline \multicolumn{2}{|c|}{.204} & .065 & .414 & 3.153 & .003 \\
\hline
\end{tabular}

a. Dependent Variable:Customer_Loyalty

Based on the output above it is known that the value of the $\mathrm{t}$ count is 3.153. Because the calculated $t$ value has been found, the next step we will look for is the t table value. The formulas for finding $t$ tables are: 
A / 2 value $=0.05 / 2=0.025$. Degree of freedom $(d f)=n-2=50-2=48$. Value of $0.025 ; 48$ then we look at the distribution of $t$ table values.

The value of t table is 2.010 because the value of the $t$ count is 3.153 greater than $>2.010$ so it can be concluded that $\mathrm{HO}$ is rejected and $\mathrm{Ha}$ is accepted. This means that "There is a Quality-of-Service Effect $(\mathrm{X})$ on student loyalty (Y)". $t$ value of 3.153 is considered greater than the value of $t$ table 2.010 in a simple linear regression analysis..

\section{Hypothesis Testing by Looking at the Regression Curve}

Testing using a regression curve will be useful if the calculated t value is found to be positive (+) which is 3,153 .

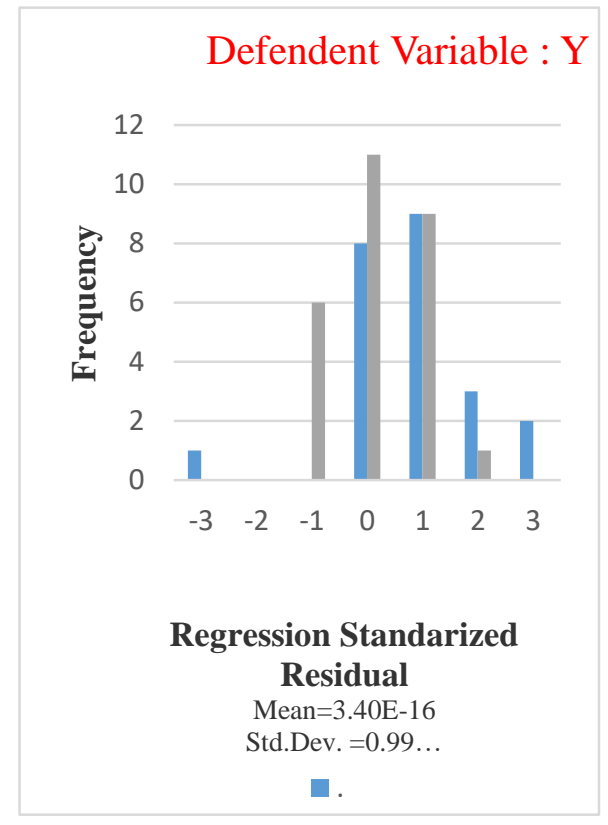

Based on the above curve it is known that the value of $t$ count of 3.153 lies in the area of positive influence. So it can be concluded that "There is a positive effect of Service Quality (X) on Loyalty_ students (Y)".

\section{Seeing the Magnitude of the Effect of Variable $X$ on $Y$}

To find out the magnitude of the effect of Quality_man (X) on Loyalty_students (Y) in a simple linear regression analysis based on the value of R. Square or R2 which is obtained in the SPSS output part of the capital summary.

Figure 1. Histogram Curve

Table 5. Model Summary

\begin{tabular}{|c|c|c|c|c|}
\hline Model & $\mathrm{R}$ & R Square & $\begin{array}{c}\text { Adjusted R } \\
\text { Square }\end{array}$ & $\begin{array}{c}\text { Std.Error } \\
\text { the Estimate }\end{array}$ \\
\hline 1 & $.414^{\mathrm{a}}$ & .172 & .154 & .14821 \\
\hline
\end{tabular}

a. Predictors: (Constant), Service_Quality

b. DependetVariable: Customer_Loyalty

From the output above, it is known that the R Square value is 0.172 . This value implies that the effect of service quality $(\mathrm{X})$ on student loyalty $(\mathrm{Y})$ is $17.2 \%$ while $82.8 \%$ of student loyalty is influenced by other variables not examined. 
[4] R. M. Cortez and W. J. Johnston, "The future of B2B marketing theory : A historical and prospective analysis," Ind. Mark. Manag., no. July, pp. 0-1, 2017.

\section{CONCLUSION}

Referring to the explanation above, we can conclude that "Quality of service (X) has a positive effect on customer loyalty (Y) with a total influence of $17.2 \%$. This positive effect means increasing the Quality of Service (X) Shopee will affect the increase in Loyalty. Y).

\section{SUGGESTION}

In the research that has been done, this requires some suggestions for further development. In this study, only measuring the variable quality of service and customer loyalty, it is expected that in future studies to continue and develop this research. It is expected that the results of this study can be used as a reference for future research. And can add other independent variables not included in this study that might affect loyalty

\section{REFERENCES}

[1] A. Ibrahim, E. S. and Z. Adetya, "Analysis of weakness of data validation from social CRM," in Proceedings of 2017 International Conference on Data and Software Engineering, ICoDSE 2017, Palembang, 2017.

[2] A. Ibrahim, . A. Turrahma, and L. Ruskan, "The implementation of customer relationship management $(\mathrm{crm})$ with service oriented architecture (soa) to improve customers' loyalty," in International Conference on Information System, Computer Science and Engineering 2018, ICONISCSE 2018; Palembang, 2018.

[1] Z. Soltani, B. Zareie, F. Shari, and N. Jafari, "Journal of High Technology Management Research The impact of the customer relationship management on the organization performance," vol. 29, no. November, pp. 237-246, 2018.

[2] W. Reinartz, M. Krafft, and W. D. Hoyer, "The Customer Relationship Management Process : Its Measurement and Impact on Performance," vol. XLI, no. August, pp. 293-305, 2004.

[3] F. Authors, "Customer relationship management capabilities Measurement, antecedents, and consequences," 2014.
[5] W. G. Mangold and D. J. Faulds, "Social media: The new hybrid element of the promotion mix," 2009.

[6] T. Hennig-Thurau et al., "The Impact of New Media on Customer Relationships," no. 2009, pp. 311-330, 2010.

[7] E. Dan and B. Universitas, "Analysis Of E-Service Quality And Values Accepted To Customer Loyalty In Online Purchase Through Shopee. Co. Id In Faculty," 2018.

[8] S. Widjoyo, P. Hatane, R. K. M. R. Brahmana, J. M. Pemasaran, U. K. Petra, and J. Siwalankerto, " The influence of service quality and product quality on customer satisfaction and customer loyalty to happy garden restaurants in Surabaya," vol. 2, no. 1, pp. 1-9, 2014.

[9] L. N. Bank and K. Wijayanto, "Effect of service quality on bank customer satisfaction and loyalty," pp. 38-45.

[10] I. J. Sembiring, "Customer Satisfaction In Forming Customer Loyalty (Study on McDonald's Customers MT. Haryono Malang)" vol. 15, 1, pp. 1-10, 2014.

[11] A. Oriade and P. Scho, "Journal of Destination Marketing \& Management An examination of the role of service quality and perceived value in visitor attraction experience," vol. 11, no. October 2018, pp. 1-9, 2019.

[12] R. Belwal and M. Amireh, "ScienceDirect Service quality and attitudinal loyalty : Consumers ' perception of two major telecommunication companies in Oman," AEBJ, vol. 13, no. 2, pp. 197-208, 2018.

[13] A. Meesala and J. Paul, "Journal of Retailing and Consumer Services Service quality, consumer satisfaction and loyalty in hospitals : Thinking for the future," J. Retail. Consum. Serv., no. October 2015, pp. 1-9, 2016.

[14] F. Cheng, C. Wu, and Y. Chen, "Computers in Human Behavior Creating customer loyalty in online brand communities," Comput. Human Behav., no. 181, pp. 0-1, 2018. 
[15] K. Pt et al., "influence of customer relationship management and confidence towards satisfication as well as a result of loyalty" vol. 3, 2, pp. 671-683, 2015.

[16] M. R. Istambul, "The Role of Customer Relationship Management in Improving Customer Service by the Company," 2006.

[17] K. C. Laudon and C. G. Traver, Ecommerce. 2016.

[18] O. Dyanna, M. Afrina, and A. Ibrahim, "Web-based Customer Relationship Management (CRM) Application (Case Study of YEN-YEN Store Marketing Information Systems) 1,2,3," vol. 4, 2, pp. 516-529, 2012.

[19] M. Kubina and V. Lendel, "Successful Application of Social CRM in The Company," Procedia Econ. Financ., vol. 23, no. October 2014, pp. 1190-1194, 2015.

[20] A. Ahani, N. Zairah, A. Rahim, and M. Nilashi, "Forecasting social CRM adoption in SMEs : A combined SEM-neural network method," Comput. Human Behav., vol. 75, pp. 560-578, 2017.

[21] F. Kawaf and D. Istanbulluoglu, "Journal of Retailing and Consumer Services Online fashion shopping paradox : The role of customer reviews and Facebook marketing," J. Retail. Consum. Serv., vol. 48, no. February, pp. 144-153, 2019.

[22] S. Sohn, "Journal of Retailing and Consumer Services A contextual perspective on consumers â€TM perceived usefulness : The case of mobile online shopping," J. Retail. Consum. Serv., vol. 38, no. January, pp. 22-33, 2017.

[23] J. Kim, M. Kim, J. Choi, and M. Trivedi, "Offline social interactions and online shopping demand: Does the degree of social interactions matter?," J. Bus. Res., no.

November 2016, pp. 1-8, 2017.

[24] J. Koiwanit, "SC," Adv. Clim. Chang. Res., 2018.

[25] T. Liao, "International Journal of Information Management Online shopping postpayment dissonance : Dissonance reduction strategy using online consumer social experiences,” Int. J. Inf. Manage., vol. 37, no. 6, pp. 520-538, 2017. 